\title{
THE ROLE OF 21-HYDROXYLASE DEFICIENCY IN THE PATHOGENESIS OF BEHÇET DISEASE
}

\section{BEHÇET HASTALIĞI PATOGENEZINDE 21-HIDROKSILAZ EKSIKLİĞİIN ROL $\ddot{U}$}

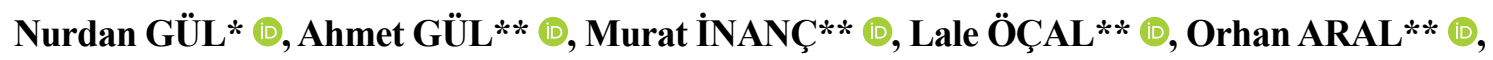 \\ Faruk ALAGÖL*
}

\begin{abstract}
Objective: Acne-like skin lesions and more severe disease course in males suggest a role for sex hormones in the pathogenesis of Behçet disease (BD). HLA-B51 is the main genetic susceptibility factor for BD, and CYP21A2 gene responsible for most of congenital adrenal hyperplasia $(\mathrm{CAH})$ is located within the MHC locus on chromosome 6p21.3. We aimed to investigate the possible role of 21-hydroxylase deficiency in linkage disequilibrium with HLA-B51 and causing androgen excess.

Materials and Methods: We studied 18 healthy controls, 29 BD patients and 15 patients with ankylosing spondylitis (AS). All subjects underwent ACTH stimulation test. Basal and stimulated serum cortisol and 17-OH-progesterone (17-OH-P) levels and basal dehydroepiandrosterone sulfate (DHEA-S), total testosterone and sex hormone binding globulin (SHBG) levels were measured.

Results: According to current guidelines, we accepted $10 \mathrm{ng} / \mathrm{mL}$ as the cut-off point for $17-\mathrm{OH}-\mathrm{P}$ to define non-classic $\mathrm{CAH}(\mathrm{NCAH})$. After ACTH stimulation 3 of BD patients (10.3\%) and 5 AS patients (33.3\%) had high 17-OH-P concentrations. Those individuals were considered as $\mathrm{NCAH}$ or possible carriers for $\mathrm{CAH}$ mutations. Three out of $8 \mathrm{BD}$ patients with prominent acne were identified as NCAH biochemically. Mean total testosterone levels of BD patients were significantly lower than those of healthy controls, however these levels were normal in BD patients with high 17-OH-P.

Conclusion: This preliminary work documented high 17-OH-P levels following ACTH stimulation in a subset of BD and AS patients, and genetic studies are necessary to investigate the role of 21-hydroxylase deficiency in association with HLA-B alleles in their pathogenesis.

Keywords: 21-hydroxylase deficiency; Behçet disease; Ankylosing spondylitis; HLA-B51; HLA-B27; CYP21A2 gene.

\section{ÖZET}

Amaç: Akne benzeri deri lezyonlarının sıklığı ve hastalığın erkeklerde daha ağır seyretmesi Behçet hastalığı (BH) patogenezinde seks hormonlarının rolünün olabileceğini düşündürmektedir. HLA-B51 BH için en önemli genetik duyarll1ık faktörüdür. Konjenital adrenal hiperplazilerin (KAH) çoğundan sorumlu olan CYP21A2 geni kromozom 6p21.3'deki MHC bölgesinde yerleşimlidir. Bu çalışmada CYP21A2 genindeki olası bazı mutasyonların HLA-B51 ile bağlantı dengesizliği
\end{abstract}

Cite this article as: Gül N, Gül A, İnanç M, Öçal L, Aral O, Alagöl F. The role of 21-hydroxylase deficiency in the pathogenesis of Behçet Disease. J Ist Faculty Med 2018;81(1): 11-6.

Date received/Dergiye geldiği tarih: 05.02.2018 - Date accepted/Dergiye kabul edildiği tarihi: 19.02.2018 Istanbul University, Istanbul Faculty of Medicine, Department of Internal Medicine, *Division of Endocrinology and Metabolism and ${ }^{* *}$ Division of Rheumatology, Istanbul, Turkey (İletişim kurulacak yazar/Corresponding author: n_gul@hotmail.com) 


\section{1-hydroxylase deficiency in Behçet Disease}

göstererek 21-hidroksilaz eksikliğine ve bunun sonucunda androjen fazlalı̆̆ına yol açarak BH patogenezine katkı yapabileceği hipotezini araştırmayı amaçladık.

Gereç ve Yöntem: Çalışma grubunu 18 sağlıklı kontrol, 29 BH olan hasta ve 15 ankilozan spondilit (AS) hastası oluşturdu. Bütün hastalara ACTH uyarı testi yapıldı. Bazal ve ACTH uyarısı sonras1 serum kortizol ve 17-OH-progesteron (17-OH-P) düzeyleri ve bazal dehidroepiandrosteron sülfat (DHEA-S), total testosteron ve seks hormonu bağlayıcı globulin (SHBG) düzeyleri ölçüldü.

Bulgular: Kılavuzların önerdiği şekilde, klasik olmayan KAH tanısı için 17-OH-P için eşik değer olarak $10 \mathrm{ng} / \mathrm{mL}$ alındı. ACTH uyarısı sonrası 3 BH (\%10,3) ve 5 AS hastasının (\%33,3) 17-OH-P düzeyleri yüksek bulundu. Bu hastaların klasik olmayan KAH hastaları ya da KAH mutasyonları için taşıyıcı olabileceği düşünüldü. Belirgin aknesi olan 8 BH'dan üçünün biyokimyasal değerleri klasik olmayan $\mathrm{KAH}$ ile uyumluydu. $\mathrm{BH}$ olanların ortalama total testosteron düzeylerinin sağlıklı kontrollerinkinden anlamlı olarak düşük olduğu görüldü. Bununla birlikte 17-OH-P düzeyi yüksek olan hastalarda testosteron düzeyleri normaldi.

Sonuç: Bu pilot çalışmada BH ve AS hastalarının bir grubunda ACTH uyarısı sonrası yüksek 17-OH-P değerleri gözlemledik. Bulgularımız HLA-B allelleri ile bağlantı dengesizliği gösteren olası 21-hidroksilaz eksikliğinin patogeneze katkısının olabileceğini düşündürmekte ve verilerin genetik çalışmalarla doğrulanmasını gerektirmektedir.

Anahtar Kelimeler: 21-hidroksilaz eksikliği; Behçet hastalı̆̆1; Ankilozan spondilit; HLA-B51; HLA-B27; CYP21A2 geni.

\section{INTRODUCTION}

Behçet disease (BD) is a multisystem inflammatory disorder characterized mainly by recurrent oral and genital aphthous ulcers, skin lesions, and posterior segment uveitis. The etiology of BD is yet unknown, but it is generally considered to be multifactorial with an important contribution of genetic factors and environmental triggers, including microbial agents such as streptococci and herpes viruses (1). HLA-B51 is the strongest genetic susceptibility factor described so far, and several other non-HLA polymorphisms contribute to the tendency for BD phenotype (2). BD has a worse prognosis in young and male patients suggesting a role for sex hormones $(3,4)$. Increased frequency of acne-like lesions and sebum production further supports the contribution of male hormones to the $\mathrm{BD}$ pathogenesis (5).

Congenital adrenal hyperplasia $(\mathrm{CAH})$ is a group of autosomal recessively inherited disorders, which are clinically characterized by different degrees of virilization and salt wasting caused by deficiency of enzymes involved in biosynthesis of steroid hormones $(6,7)$. The most common form of CAH is due to mutations in the CYP21A2 gene leading to 21-hydroxylase deficiency, which results in a decrease in cortisol synthesis at varying levels and overproduction of cortisol precursors and sex steroids (6). Classic form of CAH may be life threatening and usually diagnosed very early in life (7). However, patients with non-classic forms of the disease may usually present after puberty, with clinical manifestations such as acne, hirsutism, menstrual disturbances and infertility, reflecting androgen excess instead of adrenal insufficiency (8). Refractory acne may be the main clinical manifestation of those patients. On the other hand, some of the non-classic $\mathrm{CAH}(\mathrm{NCAH})$ patients may be asymptomatic and can only be diagnosed during screening of families with affected members (8). Classic CAH patients carry mutations causing severe defects in function such as zero to $5 \%$ enzyme activity in both alleles, but about one half to two thirds of patients with NCAH are compound heterozygotes for mutations causing both mild and severe defects in enzyme function (8).

Mutations associated with $\mathrm{CAH}$ and $\mathrm{NCAH}$ were known to be in linkage disequilibrium with HLA-B alleles, because of strong linkage disequilibrium in the major histocompatibility region (6,9-12). HLA-B51 has been listed among the alleles associated with non-classic CYP21A2 mutations (13,14). Since 21-hydroxylase deficiency associated NCAH is a relatively common autosomal recessive disorder (15), we herein aimed to investigate the possible role of 21-hydroxylase deficiency in linkage disequilibrium with HLA-B51 and causing androgen excess in the pathogenesis of $\mathrm{BD}$, and we included another HLA Class I associated disease with male predominance, ankylosing spondylitis (AS) as disease control group. 


\section{MATERIALS AND METHODS}

\section{Patients}

Study group consisted of 18 healthy controls, and 29 patients with BD, who fulfilled the International Study Group Criteria for the diagnosis. Also, 15 patients with AS, who met the modified New York criteria, included into the study. The patient group was selected from Outpatient Clinic as consecutive patients with known HLA status and consenting to participate in the study.

All the patients and healthy controls were clinically evaluated for acne, hirsutism, short stature, premature puberty, menstrual dysfunction and infertility using a standard chart. None of the patients or controls was using glucocorticoids or oral contraceptives that may affect the hormonal evaluation.

\section{Methods}

All of the patients and healthy controls underwent a diagnostic protocol that included basal serum 17-hydroxyprogesterone (17-OH-P), cortisol, dehydroepiandrosterone sulfate (DHEA-S), total testosterone and sex hormone binding globulin (SHBG) levels and an ACTH-stimulation test. Stimulation test was done by intravenous bolus injection of $0.25 \mathrm{mg} 1-24 \mathrm{ACTH}$ (Synacthen; Ciba/Novartis, Basel, Switzerland), and venous blood samples were collected 30 and $60 \mathrm{~min}$ later for the measurement of cortisol and 17-OH-P concentrations. All samples were obtained after an overnight fasting, in the early morning between 8 and 9 o'clock and between day 3 and 8 of the menstrual cycle of the female participants. Samples were immediately centrifuged, and serum was separated and frozen at $-20^{\circ} \mathrm{C}$ until analyzed. Informed consent was obtained from all the participants, and Istanbul Faculty of Medicine Research Ethics Committee approved the study protocol.

\footnotetext{
Assays

Serum cortisol levels were measured with Amerlite Cortisol Assay (Ortho-Clinical Diagnostics, Amersham, UK) using a competitive immunoassay technique. Serum 17-OH-P, DHEA-S and testosterone levels were measured with Diagnostic Systems Laboratories (DSL) (Webster, TX) radioimmunoassay kit. SHBG levels were measured with Euro-Diagnostica (Malmö, Sweden) radioimmunoassay (RIA) kit.
}

\section{Statistical Analysis}

Mean values with standard deviation (SD) were calculated, and those values were compared with Student $t$ test for parametric, and Mann-Whitney $U$ test for non-parametric variables. $\mathrm{P}<0.05$ was considered statistically significant for all analyses. Statistical analyses were done by Statistical Package for the Social Sciences for Windows (Release 5.0.1. SPSS Inc.; Chicago, IL, USA).

\section{RESULTS}

The mean age $( \pm \mathrm{SD})$ of the healthy controls $(8 \mathrm{fe}-$ males/10 males) was $29 \pm 5.3$ (range, 22-40), of BD patients (14 females/15 males) was $41 \pm 9.6$ (range, 24-60), of AS patients ( 3 females/12 males) was $29 \pm 8.7$ (range, 16-44). Only 8 out of 29 patients with $\mathrm{BD}$ and 1 out of 15 patient with AS had acne or history of acne.

According to the current approach $(7,15)$, we accepted $10 \mathrm{ng} / \mathrm{mL}$ concentration of $17-\mathrm{OH}-\mathrm{P}$ as the cut-off point to define NCAH. After ACTH stimulation 3 of BD patients (10.3\%) and $5 \mathrm{AS}$ patients $(33.3 \%)$ had increased 17-OH-P concentrations $>10 \mathrm{ng} / \mathrm{mL}$. Clinical and laboratory features of those BD and AS patients are given in Table 1. Two of the BD patients (66.6\%) were HLA-B51 positive, and four of the AS patients $(80 \%)$ were HLA-B27 positive (Table 2). Two of AS patients were also carrying HLA-B51.

In one of the healthy controls with high basal level (3.4 $\mathrm{ng} / \mathrm{mL}$ ), $17-\mathrm{OH}-\mathrm{P}$ value was found to be $9.9 \mathrm{ng} / \mathrm{mL}$ after stimulation, and his result was considered as borderline positive.

Those 3 patients with BD, 5 patients with AS and one of healthy controls were considered as NCAH or possible heterozygous carriers of CYP21A2 mutations for $\mathrm{CAH}$. Mean total testosterone levels of BD patients were significantly lower than those of healthy controls, however these levels were within normal limits in BD patients with high stimulated 17-OH-P (Table 2).

\section{DISCUSSION}

This preliminary study identified $10.3 \%$ of the BD and $33.3 \%$ of the AS patients with high 17-OH-P levels following ACTH stimulation. High 17-OH-P levels suggesting 21-hydroxylase deficiency was observed in $37.5 \%$ of the BD patients with prominent acne, and just 


\section{1-hydroxylase deficiency in Behçet Disease}

Table 1. Clinical and laboratory features of 3 Behçet disease and 5 ankylosing spondylitis patients with high 17-OH-P results after ACTH stimulation

\begin{tabular}{|c|c|c|c|c|c|c|c|c|c|}
\hline \multirow[b]{2}{*}{ Patient } & \multirow[b]{2}{*}{ Age } & \multirow[b]{2}{*}{ Sex } & \multirow[b]{2}{*}{ Acne } & \multirow[b]{2}{*}{$\begin{array}{c}\text { Total T } \\
\text { (ng/mL) }\end{array}$} & \multirow[b]{2}{*}{$\begin{array}{c}\text { SHBG } \\
(\mathrm{nmol} / \mathbf{L})\end{array}$} & \multirow[b]{2}{*}{$\begin{array}{c}\text { DHEAS } \\
(\mu \mathrm{g} / \mathrm{dL})\end{array}$} & \multicolumn{2}{|c|}{ 17-OH-P (ng/mL) } & \multirow[b]{2}{*}{$\begin{array}{c}\text { HLA-B } \\
\text { Allele }\end{array}$} \\
\hline & & & & & & & Basal & Stimulated & \\
\hline \multicolumn{10}{|c|}{ Behçet disease } \\
\hline 1 & 26 & M & Yes & 8.0 & 134.8 & 62.3 & 5.3 & 11.2 & B35/B35 \\
\hline 2 & 24 & M & Yes & 8.2 & 80 & 266.9 & 8.8 & 14.8 & B51/B45-50? \\
\hline 3 & 36 & M & Yes & 6.3 & 46.5 & 323.8 & 4.8 & 13 & B51/B55 \\
\hline \multicolumn{10}{|c|}{ Ankylosing spondylitis } \\
\hline 1 & 41 & M & No & 12.3 & 81.4 & 547.5 & 5.5 & 13.3 & $\mathrm{~B} 27$ \\
\hline 2 & 20 & M & No & 11.1 & 46.0 & 149.2 & 7.1 & 12.2 & B27 \\
\hline 3 & 44 & M & No & 3.7 & 39.0 & 283 & 1.8 & 11.5 & B51/B57 \\
\hline 4 & 27 & M & No & 7.1 & 28.8 & 425.8 & 2.9 & 11.0 & B51/B27 \\
\hline 5 & 19 & M & Yes & 13.3 & 39.8 & 296.8 & 3.8 & 10.1 & B27 \\
\hline
\end{tabular}

17-OH-P: 17-OH-progesterone; ACTH: adrenocorticotropic hormone; T: testosterone; SHBG: sex hormone binding globulin; DHEAS: dehydroepiandrosterone sulfate; HLA: human leukocyte antigen

Table 2. Serum testosterone, SHBG and DHEAS concentrations in the study group

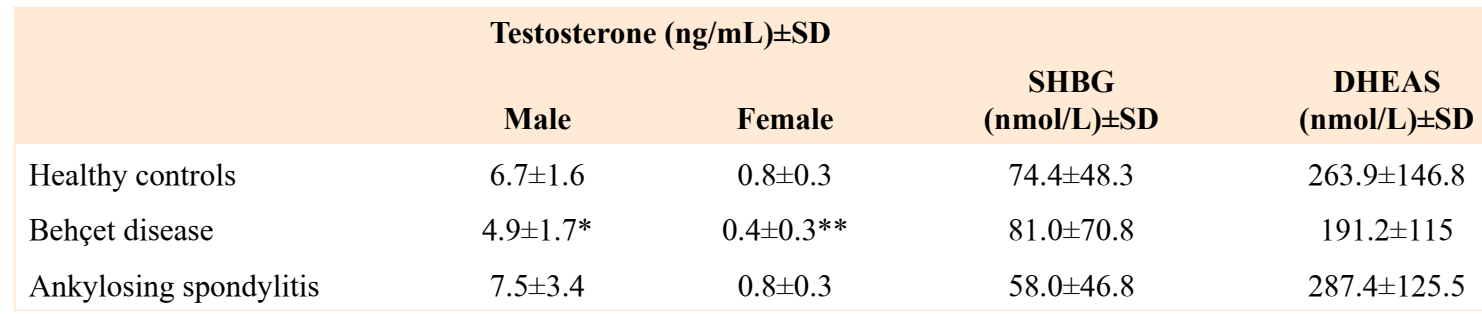

$* \mathrm{p}=0.0083, * * \mathrm{p}=0.0174$. SHBG: sex hormone binding globulin; DHEAS: dehydroepiandrosterone sulfate

one out of 15 AS patients with acne also had high stimulated 17-OH-P levels.

Potential contribution of 21-hydroxylase deficiency associated androgen excess has not been studied in $\mathrm{BD}$ and AS, despite their very strong association with HLA Class I antigens, B51 and B27, respectively. This study is the first one aiming to test the possibility of HLA haplotype associated CYP21A variants as a pilot work. Therefore, it has several limitations, especially regarding the number of subjects studied and also use of single method, the ACTH stimulation test, as a screening tool.

The prevalence of NCAH is relatively high among females with hirsutism or polycyctic ovary syndrome $(7,15-20)$, however there is no data about the frequency of mutation carriers in Turkish healthy population. On the other hand, screening methods based on basal 17-
OH-P levels have limitations, and some patients with less than suggested 17-OH-P concentration of $2 \mathrm{ng} / \mathrm{mL}$ may have $>10 \mathrm{ng} / \mathrm{mL}$ values after ACTH stimulation, similar to one of the AS patients in the study group (21,22).

There are also different views on the cut-off concentration of stimulated 17-OH-P to define $\mathrm{NCAH}$, mainly due to variations in the main aims of definitions. Current suggestion of $>10 \mathrm{ng} / \mathrm{mL} 17-\mathrm{OH}-\mathrm{P}$ is usually regarded as a sensitive level for capturing a larger group, but its specificity may be lower compared to the cut-off values such as 14 or even $15 \mathrm{ng} / \mathrm{mL}$ concentration of $17-\mathrm{OH}-$ $\mathrm{P}$ after ACTH stimulation, which reaches almost $100 \%$ specificity $(7,8,15,22,23)$.

The main aim of this study was investigation of the possibility of 21-hydroxylase deficiency in linkage disequilibrium with HLA-B51 in BD patients with manifesta- 


\section{Behçet Hastalığı ve 21-hidroksilaz eksikliği}

tions suggesting androgen access. But, higher frequency of positive results in AS patients without prominent acne or other androgen excess manifestations may require further investigations. It is necessary to note that it may be hard to detect androgen excess findings in male patients, which explains the ascertainment bias in favor of diagnosis of mainly female patients (8). On the other hand, when we accept $14 \mathrm{ng} / \mathrm{L}$ 17-OH-P level as the cutoff point, only one patient with $\mathrm{BD}$, who had prominent acne and carrying HLA-B51 allele, could be diagnosed as NCAH.

Regarding the sex hormone levels in $\mathrm{AS}$ and $\mathrm{BD}$, inconsistent results have been reported similar to unexpectedly low total testosterone levels we observed in BD patients in this study $(5,24,25)$. However, relatively higher total testosterone levels in those patients with high 17-OH-P levels can be regarded as a supporting evidence for the functional significance of ACTH-stimulation results.

\section{CONCLUSION}

The results of current study showing $10.3 \%$ of BD and $33.3 \%$ of AS patients with high ACTH-stimulated 17$\mathrm{OH}-\mathrm{P}$ levels warrant further analysis to screen CYP21A2 mutations in linkage disequilibrium with HLA-B51 and HLA-B27 by genetic methods, to confirm their role in the development of male predominant disorders.

Ethics Committee Approval: Ethics committee approval was received for this study from the Ethics Committee of Istanbul University Istanbul Faculty of Medicine.

Informed Consent: Informed consent was obtained from all participants who participated in this study.

Peer-review: Externally peer-reviewed.

Author Contributions: Concept - N.G., A.G., F.A.; Design - N.G., A.G., F.A..; Supervision - O.A., L.Ö., F.A., ; Resources - A.G., M.İ., L.Ö.; Materials - N.G.; Data Collection and/or Processing - N.G., A.G., M.İ. , L.Ö.; Analysis and/or Interpretation - N.G., A.G., F.A.; Literature Search - N.G., A.G.; Writing Manuscript N.G., A.G., F.A.; Critical Review - N.G., A.G., M.İ., L.Ö., O.A., F.A.

Conflict of Interest: No conflict of interest was declared by the authors.
Financial Disclosure: This project was supported by the Research Fund of Istanbul University (Project number: T-480/071197). Synacthen vials were kindly provided by Ciba/Novartis.

Etik Komite Onayı: Bu çalışma için etik komite onayı İstanbul Üniversitesi Tıp Fakültesi’nden alınmıştır.

Hasta Onamı: Hasta onamı bu çalışmaya katılan tüm katılımcılardan alınmıştır.

Hakem Değerlendirmesi: Dış bağımsız.

Yazar Katkıları: Fikir - N.G., A.G., F.A.; Tasarım - N.G., A.G., F.A..; Denetleme - O.A., L.Ö., F.A., ; Kaynaklar A.G., M.İ., L.Ö.; Malzemeler - N.G.; Veri Toplanması ve/ veya İşlemesi - N.G., A.G., M.İ., L.Ö.; Analiz ve/veya Yorum - N.G., A.G., F.A.; Literatür Taramas1 - N.G., A.G.; Yazıyı Yazan - N.G., A.G., F.A.; Eleştirel İnceleme - N.G., A.G., M.İ., L.Ö., O.A., F.A.

Çıkar Çatışması: Yazarlar çıkar çatışması bildirmemişlerdir.

Finansal Destek: $\mathrm{Bu}$ çalışma İstanbul Üniversitesi Bilimsel Araştırma Projeleri Koordinatörlüğü tarafindan desteklenmiştir (Yeni sağlık kod T-480/071197). Synacthen ampulleri Ciba/Novartis tarafından bağışlanmıştır.

\section{REFERENCES}

1. Gul A. Pathogenesis of Behcet's disease: autoinflammatory features and beyond. Semin Immunopathol 2015;37(4):413-8. [CrossRef]

2. Gul A. Genetics of Behcet's disease: lessons learned from genomewide association studies. Curr Opin Rheumatol 2014;26(1):56-63. [CrossRef]

3. Yazici H, Tuzun Y, Pazarli H, Yurdakul S, Ozyazgan $\mathrm{Y}$, Ozdogan H, et al. Influence of age of onset and patient's sex on the prevalence and severity of manifestations of Behcet's syndrome. Ann Rheum Dis 1984;43(6):783-9. [CrossRef]

4. Tugal-Tutkun I, Onal S, Altan-Yaycioglu R, Altunbas HH, Urgancioglu M. Uveitis in Behcet disease: an analysis of 880 patients. Am J Ophthalmol 2004;138(3):373-80. [CrossRef]

5. Yazici H, Mat C, Deniz S, Iscimen A, Yurdakul S, Tuzun Y, et al. Sebum production is increased in Behçet's syndrome and even more so in rheumatoid arthritis. Clin Exp Rheumatol 1987;5(4):371-4.

6. Dupont B, Oberfield SE, Smithwick EM, Lee TD, Levine LS. Close genetic linkage between HLA and congenital 


\section{1-hydroxylase deficiency in Behçet Disease}

adrenal hyperplasia (21-hydroxylase deficiency). Lancet 1977;2 (8052-8053):1309-12. [CrossRef]

7. Speiser PW, Azziz R, Baskin LS, Ghizzoni L, Hensle TW, Merke DP, et al. Congenital adrenal hyperplasia due to steroid 21-hydroxylase deficiency: an Endocrine Society clinical practice guideline. J Clin Endocrinol Metab 2010;95(9):4133-60. [CrossRef]

8. Witchel SF, Azziz R. Nonclassic congenital adrenal hyperplasia. Int J Pediatr Endocrinol 2010;2010:625105. [CrossRef]

9. Levine LS, Zachmann M, New MI, Prader A, Pollack MS, O'Neill GJ, et al. Genetic mapping of the 21-hydroxylase-deficiency gene within the HLA linkage group. N Engl J Med 1978;299(17):911-5. [CrossRef]

10. Bercovici JP, Khoury S, Le Fur JM, Saleun JP, Nahoul $\mathrm{K}$, Scholler R. Hormonal profiles of heterozygotes in humans for 21-hydroxylase deficiency defined by HLA B typing. J Steroid Biochem 1981;14(10):104954. [CrossRef]

11. Pollack MS, Keenan B, Christiansen FT, Cobain TJ, Dawkins RL, Clayton G. The immunological detection of a 21-OH deficiency mutation HLA supratype. Am J Hum Genet 1986;38(5):688-98.

12. White PC, Werkmeister J, New MI, Dupont B. Steroid 21-hydroxylase deficiency and the major histocompatibility complex. Hum Immunol 1986;15(4):40415. [CrossRef]

13. Velasco FJ, Pico AM, Munoz C, Mauri M, de la Sen ML. [A genetic and hormonal study of 5 patients with the nonclassical form of congenital adrenal hyperplasia due to 21-hydroxylase deficiency]. Med Clin (Barc) 1992;99(3):81-6.

14. Parlato F, Pisano G, Misiano G, Cosentini E, Cacciapuoti C, Cavalcanti MR, et al. HLADR5 and C4BQO high frequency and antinuclear antibodies positivity in patients with 21 hydroxylase deficiency from Campania region. J Endocrinol Invest 1992;15(6):429-36. [CrossRef]

15. Carmina E, Dewailly D, Escobar-Morreale HF, Kelestimur F, Moran C, Oberfield S, et al. Non-classic congenital adrenal hyperplasia due to 21-hydroxylase deficiency revisited: an update with a special focus on adolescent and adult women. Hum Reprod Update 2017;23 (5):580-99. [CrossRef]

16. Sahin Y, Kelestimur F. The frequency of late-onset 21-hydroxylase and 11 beta-hydroxylase deficiency in women with polycystic ovary syndrome. Eur J Endocrinol 1997;137(6):670-4. [CrossRef]

17. Yarman S, Dursun A, Oguz F, Alagol F. The prevalence, molecular analysis and HLA typing of late-onset 21-hydroxylase deficiency in Turkish woman with hirsutism and polycystic ovary. Endocr $\mathrm{J}$ 2004;51(1):31-6. [CrossRef]

18. Unluhizarci K, Kula M, Dundar M, Tanriverdi F, Israel $\mathrm{S}$, Colak R, et al. The prevalence of non-classic adrenal hyperplasia among Turkish women with hyperandrogenism. Gynecol Endocrinol 2010;26(2):139-43. [CrossRef]

19. Binay C, Simsek E, Cilingir O, Yuksel Z, Kutlay O, Artan S. Prevalence of nonclassic congenital adrenal hyperplasia in Turkish children presenting with premature pubarche, hirsutism, or oligomenorrhoea. Int J Endocrinol 2014;2014:768506. [CrossRef]

20. Kirac D, Guney AI, Akcay T, Guran T, Ulucan K, Turan S, et al. The frequency and the effects of 21-hydroxylase gene defects in congenital adrenal hyperplasia patients. Ann Hum Genet 2014;78(6):399-409. [CrossRef]

21. Escobar-Morreale HF, Sanchon R, San Millan JL. A prospective study of the prevalence of nonclassical congenital adrenal hyperplasia among women presenting with hyperandrogenic symptoms and signs. J Clin Endocrinol Metab 2008;93(2):527-33. [CrossRef]

22. Ghizzoni L, Cappa M, Vottero A, Ubertini G, Carta D, Di Iorgi N, et al. Relationship of CYP21A2 genotype and serum 17-hydroxyprogesterone and cortisol levels in a large cohort of Italian children with premature pubarche. Eur J Endocrinol 2011;165 (2):307-14. [CrossRef]

23. Azziz R, Dewailly D, Owerbach D. Clinical review 56: Nonclassic adrenal hyperplasia: current concepts. J Clin Endocrinol Metab 1994;78(4):810-5. [CrossRef]

24. Gooren LJ, Giltay EJ, van Schaardenburg D, Dijkmans BA. Gonadal and adrenal sex steroids in ankylosing spondylitis. Rheum Dis Clin North Am 2000;26(4):969-87. [CrossRef]

25. Gerencer M, Tajic M, Kerhin-Brkljacic V, Kastelan A. An association between serum testosterone level and HLA phenotype. Immunol Lett 1982;4(3):155-8. [CrossRef] 